\title{
Struktur Populasi Ikan Cakalang (Katsuwonus pelamis, Linnaeus 1758): Famili Scombridae: Perairan Pesisir Selatan Laut Jawa
}

\author{
(Population Structuce of (Katsuwonus pelamis, Linnaeus 1758) from Southern of Java Sea)
}

\author{
Aisya Intan Widya Satria1, Rahmat Kurnia²
}

\begin{tabular}{|c|c|}
\hline ARTIKEL INFO & ABSTRAK \\
\hline $\begin{array}{l}\text { Article History } \\
\text { Received : } 20 \text { November } 2017 \\
\text { Accepted : } 24 \text { Desember } 2017\end{array}$ & $\begin{array}{l}\text { Ikan cakalang (Katsuwonus pelamis) bagian ikan pelagis besar yang ada } \\
\text { di perairan Samudra Hindia-Selatan Jawa. Intensitas penangkapannya yang } \\
\text { tinggi berpotensi memengaruhi dinamika populasi ikan cakalang. Perubahan }\end{array}$ \\
\hline $\begin{array}{l}\text { Kata kunci: } \\
\text { Panjang, Reproduksi, Cakalang, } \\
\text { Samudra Hindia, Cilacap }\end{array}$ & $\begin{array}{l}\text { dinamika populasi tersebut, dapat diketahui dengan melihat struktur ukuran } \\
\text { dan reproduksinya. Penelitian ini dilakukan untuk mengkaji kondisi struktur } \\
\text { ukuran dan reproduksi Ikan cakalang selama Desember 2014-Maret } 2015 .\end{array}$ \\
\hline $\begin{array}{l}\text { Korespondensi Author } \\
{ }^{1} \text { Departemen Manajemen Sumberdaya } \\
\text { Perairan, Fakultas Perikanan dan } \\
\text { Ilmu Kelautan, Institut Pertanian } \\
\text { Bogor }\end{array}$ & $\begin{array}{l}\text { berat, serta rasio kelamin dan fase kematangan gonad. Hasil penelitiaan } \\
\text { diperoleh bahwa rasio kelamin jantan dan betina adalah } 1: 1,4 \text { (tidak seimbang), } \\
\text { tingkat kematangan gonad terjadi pada ukuran } 388 \mathrm{~mm} \text {. Rata-rata ukuran } \\
\text { matang gonad pada ukuran } 439,40 \mathrm{~mm} \text { dan dominan tertangkap pada ukuran }\end{array}$ \\
\hline $\begin{array}{l}\text { Bagian Manajemen Sumberdaya } \\
\text { Perikanan, Departemen Manajemen } \\
\text { Sumberdaya Perairan, Fakultas } \\
\text { Perikanan dan Ilmu Kelautan, Institut } \\
\text { Pertanian Bogor. Email: yonvitr@, } \\
\text { yahoo.com }\end{array}$ & $\begin{array}{l}349,5 \mathrm{~mm} \text {. Ikan yang dominan tertangkap memiliki hubungan panjang berat } \\
\text { yang bersifat isometrik didominasi ikan muda dan belum matang gonad } \\
\text { (unmature). Untuk itu, diperlukan strategi pemanfatan yang memperhatikan } \\
\text { asas kehati-hatian (precautionary) dalam penangkapan di area dan musim } \\
\text { penangkapan. }\end{array}$ \\
\hline
\end{tabular}

\section{PENDAHULUAN}

Ikan cakalang termasuk kelompok ikan highly migratory species yang distribusinya dari perairan tropis hingga perairan subtropis (Collette dan Nauen 1983). Uktolseja et al. (1989) menyatakan bahwa penyebaran cakalang di perairan Indonesia, meliputi Samudra Hindia (perairan Barat Sumatra, Selatan Jawa, Bali, dan Nusa Tenggara), perairan Indonesia bagian timur (Laut Sulawesi, Maluku, Arafuru, Banda, Flores, dan Selat Makassar) dan Samudra Pasifik.

Ikan cakalang termasuk komoditas ekspor maupun sebagai bahan konsumsi dalam negeri (Manik 2007). Berdasarkan data dari Ditjen Perikanan Tangkap (2014), di Samudra Hindia potensi sumberdaya ikan cakalang diduga berkisar 484.610 ton dengan persentase kenaikan rata-rata dari tahun sebelumnya sebesar $0,75 \%$. Peningkatan produksi cakalang berasal dari pusatpusat pendaratan di antaranya Pelabuhan Perikanan Samudra (PPS) Cilacap, Jawa Tengah. Kenaikan yang positif menunjukkan permintaan pasar yang tinggi. Namun, kondisi ini dapat berdampak pada peningkatan eksploitasi yang dapat memengaruhi kelestariannya. Agar dapat menjaga kelestariannya, proses pemanfaatan harus dilakukan secara rasional dengan mempertimbangkan prinsip kehati-hatian. Untuk itu, indikator biologi dan dinamika populasi dapat dipergunakan sebagai dasar pertimbangan pengelolaannya (Jamal et al. 2011; Rochman et al. 2015).

Pengetahuan tentang biologi populasi ikan merupakan dasar dalam analisis stok ikan 
(Rochman et al. 2015). Informasi tersebut, sangat penting karena dapat digunakan sebagai masukan dalam pengambilan keputusan terkait perencanaan sumberdaya perikanan (Welcomme 2001). Pengetahuan dasar mengenai aspek biologi reproduksi merupakan salah satu aspek untuk mendukung upaya pengelolaan sumberdaya ikan (Jatmiko et al. 2015). Penelitian tentang biologi reproduksi ikan dapat memberi data dan informasi penting mengenai frekuensi pemijahan, keberhasilan pemijahan, lama pemijahan, dan ukuran ikan ketika pertama kali mencapai kematangan gonad (Mardlijah dan Patria 2012; Karman et al. 2014; Jatmiko et al. 2015) termasuk waktu pemijahan (Ashida et al. 2010; Grande et al. 2014; Ashida dan Horie 2015).

Penelitian ini bertujuan untuk menjelaskan status reproduksi, kelayakan ketertangkapan berdasarkan indikator biologi reproduksi di antaranya ukuran ikan, proporsi kelamin, serta kemampun reproduksi dari telur yang dihasilkan. Informasi ini akan diperlukan untuk memetakan status kondisi ikan yang menjadi tujuan penangkapan.

\section{METODOLOGI}

\section{Lokasi Penelitian}

Penelitian dilakukan mulai dari Desember 2014-Maret 2015 berlokasi di Pelabuhan Perikanan Samudra Cilacap, Jawa Tengah. Penelitian dilaksanan di lapangan dengan mengumpulkan data secara sekaligus dan setiap waktu pengamatan. Lokasi penelitian dapar dilihat pada Gambar 1.

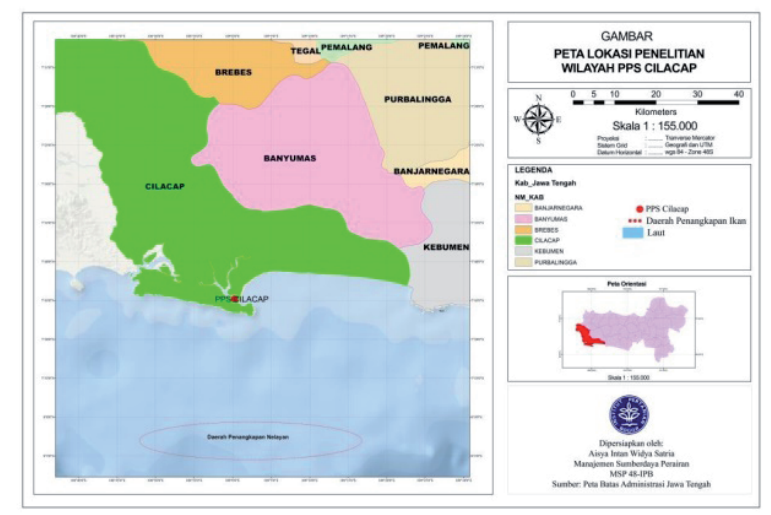

Gambar 1 Lokasi Penelitian PPS Cilacap, Jawa Tengah

\section{Prosedur \\ Pengumpulan Data}

Pengambilan ikan contoh mencakup ikan cakalang yang ditangkap mulai dari berukuran kecil, sedang, dan besar. Ikan contoh yang diukur datanya diambil secara acak dengan menggunakan teknik penarikan contoh acak sederhana (PCAS). Pengukuran data panjang dilakukan semaksimal mungkin saat pendataan. Semakin banyak ikan yang diukur makin baik datanya. Sementara itu, data untuk mengetahui jumlah jantan dan betina diamati dari sampel ikan yang dibedah. Jumlah ikan contoh yang dibedah untuk dianalisis tingkat kematangan gonad dan TKG sebanyak 32 ekor. Ikan contoh yang diukur panjang total dan ditimbang bobot basahnya di lokasi pelelangan sebanyak 822 ekor.

Pengukuran panjang total ikan dimulai dari mulut terdepan hingga ujung ekor terakhir menggunakan meteran (ketelitian $1 \mathrm{~cm}$ ). Penimbangan bobot basah total tubuh ikan menggunakan timbangan digital (ketelitian 0,05 gram). Jenis kelamin dan TKG dapat diketahui melalui pengamatan perkembangan gonad secara morfologi setelah dilakukan pembedahan. Penentuan TKG berdasarkan morfologi mengacu pada klasifikasi Orange (1961).

Data sekunder diperoleh dari bagian statistik perikanan PPS Cilacap berupa data produksi perikanan dan trip unit penangkapan setiap tahun yang didaratkan di PPS Cilacap. Informasi lain yang dikumpulkan, yaitu operasi penangkapan, daerah penangkapan, dan biaya operasi penangkapan. Data tersebut, diperoleh melalui wawancara terhadap nelayan yang menangkap ikan cakalang di PPS Cilacap.

\section{Analisis Data}

\section{Rasio Kelamin}

Rasio kelamin yaitu perbandingan antara jenis kelamin ikan jantan dan betina yang ada di perairan. Asumsi bahwa ikan yang tertangkap di perairan adalah ikan dalam kondisi acak sehingga tersebar merata menurut kelamin. Saat tertangkap, kondisi ini juga tercermin dalam kondisi yang sama sehingga dapat direpresentasikan dari proses pengamatan hasil pendaratan yang diacak. Keseragaman sebaran rasio kelamin dilakukan dengan uji Chi-Square (Steel dan Torrie 1980). Konsep rasio adalah proporsi populasi tertentu terhadap total populasi (Walpole 1995) yang dapat dirumuskan sebagai berikut:

$$
\mathrm{p}=\frac{\mathrm{n}}{\mathrm{N}}
$$

$\mathrm{p}$ adalah proporsi kelamin (jantan atau betina), $\mathrm{n}$ adalah jumlah jenis ikan jantan (ind) 
atau betina (ind), dan $\mathrm{N}$ adalah jumlah total individu ikan jantan dan betina contoh (ind). Uji khi-kuadrat (Chi-square), kemudian dilakukan untuk mengetahui proporsi antara ikan betina dan jantan dalam suatu populasi:

$$
x^{2}=\sum \frac{\left(\mathrm{o}_{\mathrm{i}}-\mathrm{e}_{\mathrm{i}}\right)}{\mathrm{e}_{\mathrm{i}}}
$$

$\chi^{2}$ adalah nilai statistik khi-kuadrat untuk peubah acak yang sebaran penarikan contohnya mengikuti sebaran khi-kuadrat, $o_{i}$ adalah sebaran ikan jantan dan betina yang diamati, serta $e_{i}$ adalah frekuensi harapan ikan jantan dan betina.

\section{Tingkat Kematangan Gonad}

Tingkat kematangan gonad (TKG) diamati secara morfologis dengan memperhatikan bentuk, warna, dan ukuran gonad ikan contoh. Pengamatan tingkat kematangan gonad didasarkan pada standar penentuan tingkat kematangan gonad ikan cakalang dari Orange 1961.

\section{Sebaran Frekuensi Panjang dan Identifikasi Kelompok Umur}

Sebaran frekuensi panjang ditentukan dari data panjang total ikan cakalang ( $K$. pelamis). Data panjang ikan cakalang dikelompokkan ke dalam beberapa kelas panjang sehingga setiap kelas panjang ke-i memiliki frekuensi (fi). Identifikasi kelompok umur yang diduga dari ukuran dilakukan dengan menganalisis frekuensi panjang melalui metode NORMSEP (Normal Separation) (FISAT II, FAO-ICLARM Stock Assesment Tool). Sebaran frekuensi panjang dikelompokkan ke dalam beberapa kelompok umur yang menyebar dengan nilai rata-rata panjang dan simpangan baku pada masing-masing kelompok umur (Gayanilo et al. 1994 in Fandri 2012). Apabila fi adalah frekuensi ikan dalam kelas panjang ke-i $(i=1,2, \ldots, N), \mu j$ adalah ratarata panjang kelompok umur ke-j dan pj adalah proporsi ikan dalam kelompok umur ke-j $(\mathrm{j}=1,2$,
..., G) maka fungsi objektif yang digunakan untuk menduga $\left\{\mu_{\mathrm{i}}, \sigma_{\mathrm{j}}, \mathrm{p}_{\mathrm{j}}\right\}$ adalah fungsi kemungkinan maksimum (maximum likelihood function):

$$
\begin{aligned}
\mathrm{L} & =\sum_{i=1}^{N} f_{i} \log \sum_{i=1}^{G} \mathrm{p}_{j} \mathrm{q}_{i j} \\
\text { dan } & q_{i j}=\frac{1}{\sigma_{j} \sqrt{2 \pi}} e^{\frac{1}{2}\left(\frac{x_{i-} \mu_{j}}{\sigma_{j}}\right)^{2}}
\end{aligned}
$$

yang merupakan fungsi kepekatan sebaran normal dengan nilai tengah $\mu \mathrm{j}$ dan simpangan baku $\sigma_{i}, x_{i}$ adalah titik tengah kelas panjang ke-i. Fungsi objektif $\mathrm{L}$ ditentukan dengan cara mencari turunan pertama $\mathrm{L}$ masing-masing terhadap $\mu_{\mathrm{j}}$, $\sigma_{\mathrm{j}}$, dan $\mathrm{p}_{\mathrm{j}}$ sehingga diperoleh dugaan $\mu_{\mathrm{i}}, \sigma_{\mathrm{j}}$, dan $\mathrm{p}_{\mathrm{j}}$ yang akan digunakan untuk menduga parameter pertumbuhan.

\section{Hubungan Panjang dan Bobot}

Analisis hubungan panjang-bobot ikan cakalang dihitung menggunakan rumus yang umum sebagai berikut (Effendie 2002):

$$
\mathrm{W}=\mathrm{aL}^{\mathrm{b}}
$$

W adalah bobot (gram), L adalah panjang $(\mathrm{mm}), \mathrm{a}$ adalah konstanta dan $\mathrm{b}$ adalah penduga pola hubungan panjang-bobot. Interpretasi dari hubungan panjang dan bobot dapat dilihat dari nilai konstanta $b$ yaitu dengan hipotesis:

1. $\mathrm{H} 0: \mathrm{b}=3$, dikatakan hubungan isometrik (pola pertumbuhan panjang sama dengan pola pertumbuhan bobot).

2. $\mathrm{H} 1: \mathrm{b} \neq 3$, dikatakan memiliki hubungan allometrik (panjang dan berat tidak seimbang)

Pola pertumbuhan allometrik ada dua macam, yaitu allometrik positif ( $b>3$ ) yang mengindikasikan bahwa pertumbuhan bobot lebih dominan dibandingkan dengan pertumbuhan panjang dan allometrik negatif $(b<3)$ yang berarti bahwa pertumbuhan panjang lebih dominan dibandingkan dengan pertumbuhan bobotnya.

Tabel 1 Klasifikasi Tingkat Kematangan Gonad (TKG)

\begin{tabular}{|c|c|l|}
\hline TKG & Keadaan Gonad & \multicolumn{1}{c|}{ Deskripsi } \\
\hline I & $\begin{array}{c}\text { Immature } \\
\text { Maturing }\end{array}$ & $\begin{array}{l}\text { Gonad memanjang, kecil hampir transparan } \\
\text { Gonad membesar, berwarna pink-krem, butiran telur belum dapat terlihat dengan kasat } \\
\text { mata }\end{array}$ \\
\hline II & Mature & $\begin{array}{l}\text { Gonad berwarna krem kekuningan, butiran telur sudah dapat terlihat dengan mata biasa } \\
\text { Butiran telur membesar dan bewarna kuning jernih, dapat keluar dengan sedikit }\end{array}$ \\
\hline IV & $\begin{array}{c}\text { Ripe } \\
\text { penekanan pada bagian perut }\end{array}$ \\
\hline V & Spent & Gonad mengecil, bewarna merah, dan banyak terdapat pembuluh darah \\
\hline
\end{tabular}

Sumber: Orange (1961) 
Selanjutnya untuk menguji hipotesis tersebut, digunakan statistik uji sebagai berikut:

$$
\mathrm{t}_{\text {hitung }}=\left|\frac{b_{1}-b}{s b_{1}}\right|
$$

Sb1 adalah simpangan baku dugaan $b 1$ atau $b$ yang dihitung dengan:

$$
S b_{1}=\frac{s^{2}}{\sum_{i=1}^{n} x_{1}^{2}-\frac{1}{n}\left(\sum_{i=1}^{n} x_{i}\right)^{2}}
$$

Selanjutnya, nilai $t_{\text {hit }}$ dibandingkan dengan nilai $t_{\text {tabel }}$ pada selang kepercayaan $95 \%$. Pengambilan keputusannya adalah jika $\mathrm{t}_{\text {hitung }}>\mathrm{t}_{\text {tabel }}$ maka tolak hipotesis nol (H0) dan jika $\mathrm{t}_{\text {hitung }}<\mathrm{t}_{\text {tabel }}$ berarti terima hipotesis nol (Walpole 1995).

\section{HASIL DAN PEMBAHASAN}

\section{Rasio Kelamin}

Jumlah keseluruhan ikan cakalang yang diamati jenis kelaminnya, yaitu 32 individu yang terdiri atas 13 individu ikan betina dan 19 individu ikan jantan. Secara keseluruhan, perbandingan antara ikan cakalang betina dan jantan yang diamati pada penelitian ini sebesar 1:1,5 atau 40,625:59,375\%. Pada hasil uji Chi-square dengan selang kepercayaan 95\%, diperoleh hasil perbandingan ikan cakalang betina dan jantan dalam suatu populasi dalam keadaan yang tidak seimbang.

Perbandingan ikan betina dan jantan -ikan betina lebih banyak, agar bertujuan untuk mempertahankan kelestarian populasi (Purwanto et al. 1986). Menurut Manik (2007) menyatakan hal yang menyebabkan rasio kelamin mungkin tidak seimbang adalah kurangnya ikan betina pada suatu perairan karena akan memijah dan akibat kematian Hasil analisis rasio kelamin setiap bulannya dapat dilihat pada Tabel 2 .

Rasio kelamin ikan cakalang dengan perbanding 40:60 di mana populasi ikan jantan lebih dominan. Bahkan pada waktu tertentu, ukuran yang tertangkap dominan ikan jantan. Pada bulan Desember, rasio betina lebih banyak yang tertangkap dari ikan jantan. hal ini dapat diduga karena aktivitas ikan betina tinggi pada saat Bulan Desember. Aktivitas ini bisa berupa proses reproduksi (breeding) atau aktivitas pemijahan (spawning). Hasil pengamatan selama bulan Desember sampai Maret sebagian besar masih belum matang gonad. Kemungkinan ini bisa juga terjadi karena pemijaham umumnya terjadi pasa kisaran suhu $28^{\circ} \mathrm{C}$ (Lahodey et al. 2008). Namun, ikan jantan berukuran besar dari $388 \mathrm{~mm}$ sudah mencapai matang gonad dalam presentase kurang dari $20 \%$. Pola ikan jantan dan betina yang belum mencapai fase kematangan yang secara bersama mengindikasikan belum terjadinya proses pemijahan.

\section{Tingkat Kematangan Gonad}

Tingkat kematangan gonad adalah tahap tertentu perkembangan gonad ikan (Effendie 2002). Pada Gambar 2 dan 3, disajikan grafik tingkat kematangan gonad (TKG) ikan cakalang betina dan jantan pada setiap pengambilan contoh berdasarkan selang kelas panjang ikan. Gambar 2 dan Gambar 3 menunjukkan bahwa, baik ikan cakalang betina maupun ikan cakalang jantan yang dominan tertangkap adalah TKG I dan TKG II. Pada penelitian ini, diambil 32 contoh gonad (13 ekor di antaranya ikan cakalang betina dan 19 ekor ikan cakalang jantan) yang diamati dan hanya ditemukan 1 ekor ikan cakalang jantan yang mencapai TKG III dan IV, dan pada ikan cakalang betina tidak ditemukannya TKG III dan TKG IV.

Tingkat kematangan gonad tertinggi akan didapatkan paling banyak pada saat pemijahan akan tiba (Effendie 2002). Koya et al. (2012) menjelaskan puncak musim pemijahan ikan cakalang di perairan Samudra Hindia mulai dari bulan Desember hingga Maret. Pada saat memijah, ikan cakalang akan bermigrasi jauh ke laut dalam sehingga peluang untuk tertangkapnya ikan cakalang betina TKG III dan TKG IV sangat kecil. Hasil penelitian Grande et al. (2014) di bagian barat Samudra Hindia menyebutkan

Tabel 2 Rasio kelamin ikan cakalang

\begin{tabular}{|l|c|r|r|r|}
\multicolumn{1}{c|}{ Waktu } & $\mathbf{n}$ & \multicolumn{2}{c|}{ Perbandingan (\%) } & Jantan \\
\hline 25 Desember 2014 & 11 & Betina & \\
\hline 27 Januari 2015 & 5 & & 54,55 & 100,00 \\
\hline 24 Februari 2015 & 7 & 0,00 & 57,14 \\
\hline 24 Maret 2015 & 9 & 42,86 & 55,56 \\
\hline Total & 32 & 44,44 & 59,375 \\
\hline
\end{tabular}




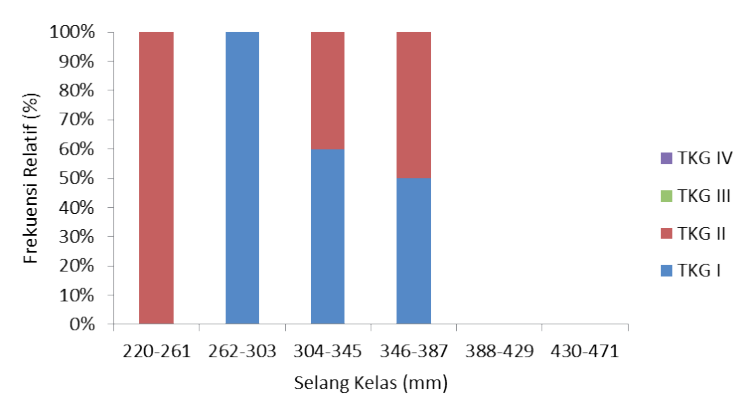

Gambar 2 Tingkat kematangan gonad ikan cakalang betina

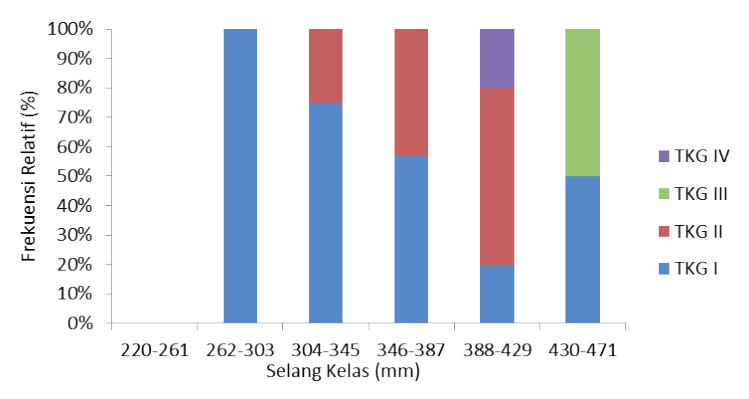

Gambar 3 Tingkat kematangan gonad ikan cakalang jantan

bahwa pemijahan ikan cakalang terjadi selama musim hujan (Januari-Februari) dan musim peralihan (Mei-Juli). Dengan demikian, Rocman et al. (2015) menduga bahwa pola rekrutmen ikan cakalang terjadi setiap tahun dengan puncaknya diduga pada bulan April sampai dengan Agustus.

Berdasarkan hasil perhitungan dengan metode Sperman Karber (Udupa 1986), dugaan ukuran pertama kali matang gonad (Lm) ikan cakalang jantan berada pada ukuran 430-471 mm, yaitu sebesar 439,40 mm. Namun untuk ikan cakalang betina, tidak ditemukannya TKG III dan TKG IV sehingga tidak didapatkan hasil ukuran pertama kali matang gonad. Hasil penelitian dari Jatmiko et al. (2015) menemukaan bahwa panjang pertama kali matang gonad ikan cakalang di Samudra Hindia adalah $429 \mathrm{~mm}$ dengan kisaran antara 416-443 mm (Sampel April hingga November). Grande et al. (2014) menyebutkan bahwa ukuran pertama kali matang gonad (Lm) ikan cakalang betina di perairan Samudra Hindia Barat diperkirakan sebesar $399 \mathrm{~mm}$. Hasil penelitian lainnya di lokasi berbeda antara lain Sumadhiharga dan Hukom (1987) diperoleh nilai $\mathrm{Lm}$ di Laut Banda sebesar $418 \mathrm{~mm}$ untuk ikan cakalang betina dan $420 \mathrm{~mm}$ untuk ikan cakalang jantan. Manik (2007) mendapatkan hasil cakalang terkecil yang sudah matang gonad
(TKG III) di perairan sekitar Pulau Seram Selatan dan Pulau Nusa Laut berukuran $436 \mathrm{~mm}$ pada jantan dan 428 pada betina. Karman et al. (2014) menyebutkan bahwa ikan cakalang pertama kali memijah di Laut Maluku adalah $430 \mathrm{~cm}$.

Berdasarkan beberapa hasil penelitian di lokasi yang berbeda menunjukkan bahwa ikan cakalang di Indonesia memijah pada ukuran $>400 \mathrm{~cm}$ dan ada perbedaan ukuran pada setiap perairan yang berbeda. Sementara di Pasifik bagian barat, ikan cakalang memijah pada ukuran $355 \mathrm{~mm}$ (Ashida et al. 2010), di Jepang ikan cakalang memijah dengan ukuran yang lebih kecil (405 $\mathrm{mm}$ jantan dan $376 \mathrm{~mm}$ betina) (Ashida dan Orie 2015). Adanya perbedaan ukuran pertama kali matang gonad ikan cakalang dipengaruhi oleh ketersediaan makanan, suhu perairan, letak lintang dan bujur, serta kecepatan pertumbuhan. Perbedaan tempat pemijahan dapat menimbulkan perbedaan musim pemijahan (Manik 2007; Ashida et al. 2010; Ashida dan Orie 2015).

Ukuran ikan yang tertangkap mencapai $79 \%$ adalah ikan yang belum dewasa (belum matang gonad). Sebanyak $21 \%$ sudah mencapai fase kematangandanreproduksi. Aktivitaspenangkapan bulan Desember hingga Maret cenderung menangkap ikan yang masih tumbuh menuju populasi matang gonad. Aktivitas penangkapan ikan bergerombol di objek mengapung (FAD) juga dapat berpengaruh pada ukuran hasil tangkapan yang cenderung seragam (Robert et al 2014). Bila kondisi ini sama dengan bulan lainnya, sangat berpotensi mengganggu kelangsungan populasi menjadi ikan dewasa sehingga proses regenerasi bisa terhambat. Namun demikian, pertumbuhan yang cepat mencapai 0,8 per tahun (Evenson 2015) juga berpotensi mempercepat ketersediaan ikan cakalang dibandingkan tropikal tuna lainnya. Namun demikian, penangkap populasi dewasa juga berdampak pada pengurangan ukuran dewasa karena kemampuan recovery yang relatif lambat untuk skipjack tuna (Hallier 2015) dari kajian di Indian Ocean.

\section{Sebaran Frekuensi Panjang dan Identifikasi Kelompok Umur}

Dari total contoh yang diamati sebanyak 822 ind ikan cakalang, sebaran frekuensi panjang ikan cakalang menyebar dari selang kelas panjang $220 \mathrm{~mm}$ hingga $791 \mathrm{~mm}$. Frekuensi tertinggi terdapat pada selang kelas 324-375 mm. Apabila dibandingkan dengan penelitian Rochman et al. (2015) di Selatan Jawa menemukan ukuran 
cakalang yang tertangkap adalah 200-650 mm. Hasil penelitian Jatmiko et al. (2015) di perairan timur Samudra Hindia panjang ikan cakalang total berkisar antara 350-680 mm. Anggraeni et al. (2015) menemukan panjang ikan cakalang total yang tertangkap pada perairan Samudra Hindia Selatan Yogya bekisar antara 200-680 mm. Hasil penelitian lainnya di Indonesia oleh Sumadhiharga dan Hukom (1987) menyatakan bahwa sebaran frekuensi panjang ikan cakalang di Laut Banda yaitu 300-699 mm. Uktolseja (1987) menemukan frekuensi panjang ikan cakalang di perairan sebelah timur Sulawesi Tengah tersebar di antara 271-577 $\mathrm{mm}$. Suwartana (1986) yang meneliti di perairan Maluku Tengah mendapatkan panjang baku berkisar antara 403-654 mm. Selanjutnya, Jamal et al. (2011) menemukan panjang ikan cakalang di Perairan Teluk Boneadalah 315-429 mm.

Karman et al. (2014) menemukan panjang ikan cakalang total yang tertang kap di Laut Maluku berkisar antara 260-720 mm. Menurut Jamal et al. (2011); Rochman et al. (2015); dan Ashida dan Orie (2015), menjelaskan bahwa jika pada suatu perairan terdapat perbedaan ukuran dan jumlah ikan, hal tersebut mungkin disebabkan oleh perbedaan pola pertumbuhan, perbedaan ukuran pertama kali matang gonad, perbedaan masa hidup, dan adanya pemasukan jenis ikan atau spesies baru pada suatu populasi ikan yang sudah ada. Spesies ikan yang sama dan hidup di lokasi perairan yang berbeda akan mengalami pertumbuhan yang berbeda karena adanya faktor dalam dan faktor luar yang memengaruhi pertumbuhan ikan tersebut. Faktor dalam tersebut, yaitu faktor yang umumnya sulit dikontrol, seperti keturunan, jenis kelamin, umur, serta penyakit (Effendie 2002). Faktor luar yang utama memengaruhi petumbuhan ikan adalah suhu dan makanan (Manik 2007; Effendie 2002).

Bedasarkan hasil tingkat kematangan gonad (Lm), diketahui bahwajumlah ikan yang ukurannya lebih kecil dari ukuran pertama kali matang gonad sebanyak 657 ekor atau 79,93\%. Hal ini karena persantase yang belum matang gonad lebih besar dari $50 \%$. Kondisi ini menunjukkan bahwa telah terjadi gejala recuitment overfishing stok ikan cakalang di peraian selatan Jawa. Kondisi juga ditemukan di perairan Laut Maluku (Karmanu et al. 2014).

Analisis kelompok umur dilakukan setelah mengetahui sebaran distribusi frekuensi panjang total ikan contoh. Analisis sebaran frekuensi panjang dapat digunakan untuk menduga umur ikan dan kelompok umur ikan. Hal ini dikarenakan frekuensi panjang ikan tertentu menggambarkan umur yang sama dan cenderung membentuk sebaran normal. Gambar 5 menyajikan hasil analisis pemisahan kelompok ukuran ikan cakalang menurut waktu pengamatan.

Berdasarkan Gambar 5 dapat dilihat bahwa terjadi pergesaran modus ke arah kanan pada bulan Desember hingga Januari dan Februari hingga Maret. Pergeseran ke arah kanan menunjukkan pertumbuhan ikan cakalang. Metode yang digunakan untuk analisis kelompok umur adalah metode NORMSEP melalui program FISAT II. Hasil analisis kelompok umur ikan cakalang berupa panjang rata-rata dan indeks separasi yang disajikan pada Tabel 3. Tabel 3 menunjukkan nilai indeks sparasi lebih dari $2(>2)$ sehingga hasil pemisahan kelompok umur ikan cakalang dapat diterima dan digunakan untuk analisis berikutnya.

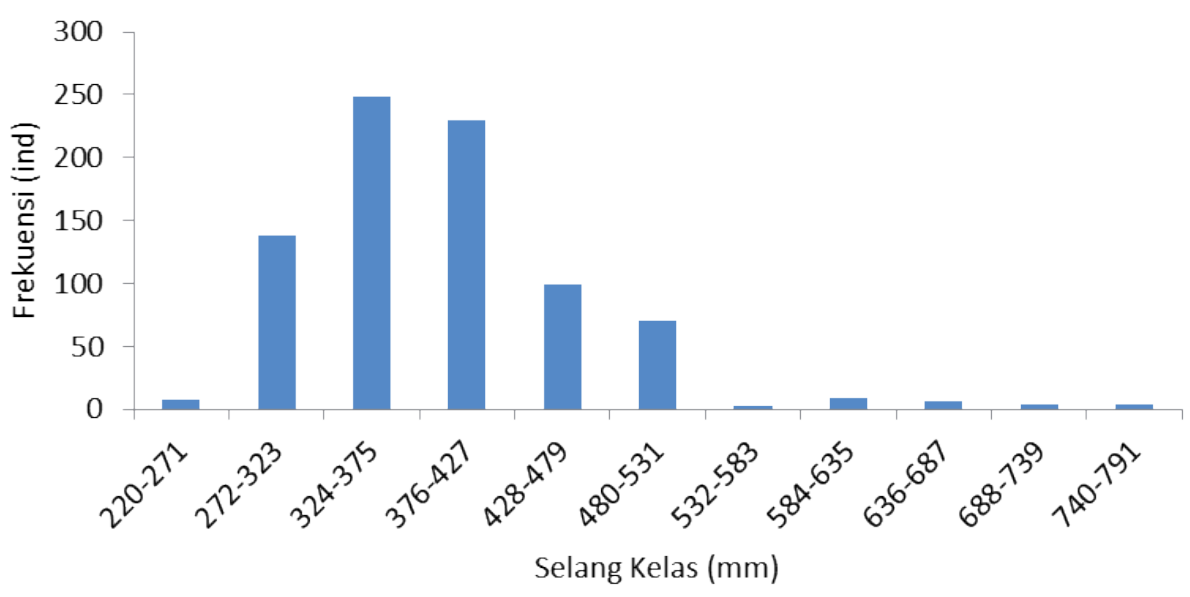

Gambar 4 Sebaran frekuensi panjang total contoh 

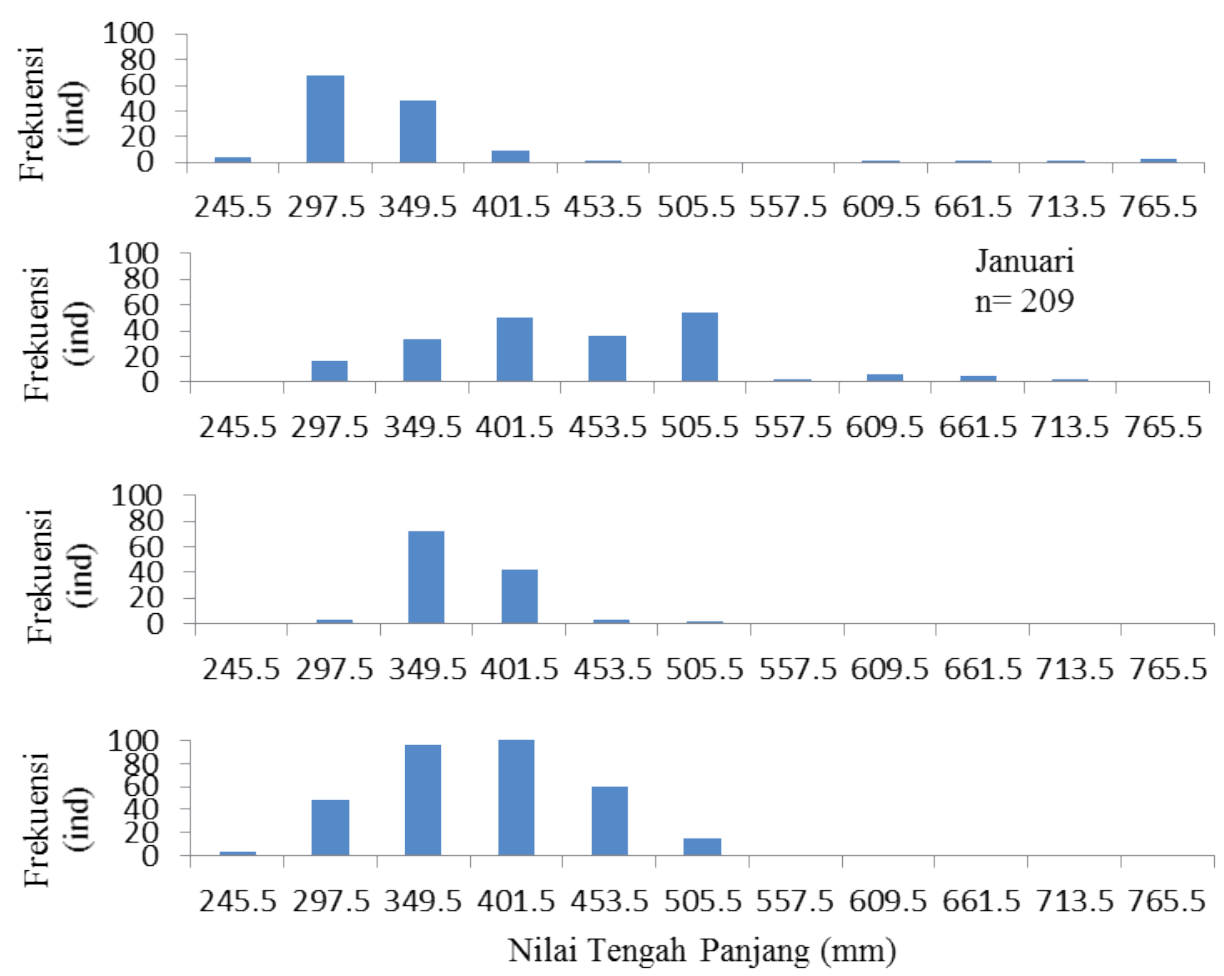

Gambar 5 Pergeseran modus frekuensi panjang ikan cakalang

Menurut Spare dan Venema (1999), indeks separasi menggambarkan kualitas pemisahan dua kelompok umur yang berdekatan.

Tabel 3 Sebaran kelompok umur ikan cakalang

\begin{tabular}{|c|c|c|c|}
\hline $\begin{array}{c}\text { Waktu } \\
\text { Pengambilan } \\
\text { Contoh }\end{array}$ & $\begin{array}{l}\text { Kelompok } \\
\text { Umur }\end{array}$ & $\begin{array}{c}\text { Panjang Rata } \\
\text { - rata Total }\end{array}$ & $\begin{array}{c}\text { Indeks } \\
\text { Separasi } \\
\text { Total }\end{array}$ \\
\hline \multirow[t]{2}{*}{25 Desember 2014} & 1 & $323,5 \pm 35,62$ & N.A \\
\hline & 2 & $713,48 \pm 60,17$ & 8,059 \\
\hline \multirow[t]{3}{*}{27 Januari 2015} & 1 & $387,18 \pm 52,91$ & N.A \\
\hline & 2 & $469,42 \pm 26,00$ & 2,769 \\
\hline & 3 & $651,11 \pm 54,09$ & 3,863 \\
\hline \multirow{2}{*}{24 Februari 2015} & 1 & $366,73 \pm 28,70$ & N.A \\
\hline & 2 & $471,53 \pm 75,33$ & 2015 \\
\hline \multirow[t]{3}{*}{24 maret 2015} & 1 & $302,42 \pm 26,00$ & N.A \\
\hline & 2 & $393,66 \pm 50,95$ & 2,372 \\
\hline & 3 & $609,64 \pm 26,00$ & 5,614 \\
\hline
\end{tabular}

\section{Hubungan Panjang dan Bobot}

Hubungan panjang bobot ikan cakalang dapat dilihat pada Gambar 6. Persamaan hubungan panjang bobot ikan cakalang adalah $\mathrm{W}=0,00001 \mathrm{~L}^{3,020}$ dengan koefisien determinasi $85,4 \%$ dan nilai b sebesar 3,020. Selanjutnya, dilakukan uji $\mathrm{t}$ $(\alpha=0,05)$ terhadap nilai $b$ diperoleh pola pertumbuhan ikan cakalang adalah isometrik yang berarti pertumbuhan bobot sama dengan pertumbuhan panjangnya. Pola pertumbuhan yang sama terdapat pada ikan cakalang yang hidup di perairan, Teluk Bone (Jamal et al. 2011), dan Laut Maluku (Karman et al. 2015). Selain itu juga, terdapat pola pertumbuhan ikan cakalang yang berbeda pada perairan di perairan sekitar Pulau Seram Selatan dan Pulau Nusa Laut yang memiliki pola pertumbuhan Allometrik Positif dengan nilai $\mathrm{b}=3,285$ (Jantan) dan $\mathrm{b}=3,355$ (betina) (Manik 2007) yang berarti bahwa pertumbuhan bobot lebih dominan dibandingkan dengan pertumbuhan panjang. Hasil penelitian Anggareini et al. (2015) juga mendapatkan ikan cakalang di Selatan Jawa dengan kategori allometrik positif $(b=3,29)$.

Berbedanya hasil analisis tersebut, diduga karena diferensiasi kisaran panjang ikan yang dianalisis cukup besar. Selain itu juga, pengaruh faktor-faktor biologis dan ekologis dari masing -masing perairan di mana ikan tersebut hidup. Menurut Manik (2007) dan Karman et al. (2015), perbedaan pola pertumbuhan dipengaruhi oleh perbedaan musim dan tingkat kematangan gonad, serta aktivitas penangkapan. Aktivitas penangkapan yang cukup tinggi pada suatu daerah akan memengaruhi kehidupan dan pertumbuhan populasi ikan. Selain itu, perbedaan pola pertumbuhan juga dapat disebabkan oleh perbedaan jumlah dan variasi ukuran ikan yang diamati (Jamal et al. 2015). 


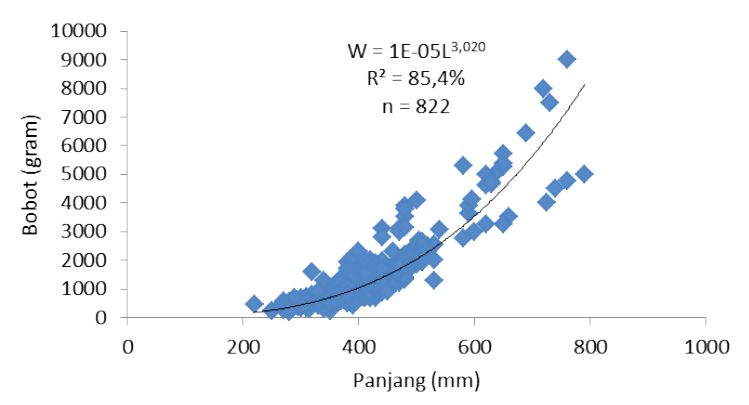

Gambar 6 Hubungan panjang bobot ikan cakalang

Ikan cakalang yang tertangkap pada ukuran di atas matang gonad yang lebih sedikit, namun relatif lebih panjang dari yang tidak matang gonad. Sebagian besar ikan yang berukuran besar ditemukan pada bulan Januari serta bulan Maret dalam populasi yang lebih sedikit. Kecilnya populasi yang berukuran dewasa menjadi indikator bahwa ikan yang tertangkap relatif seragam. Ikan cakalang memiliki karakter yang bergerombol sejak kecil sampai dewasa sehingga ikan tumbuh dan berkembang pada kondisi yang sama (dominan satu kohort). Akibatnya, akan memiliki pertumbuhan yang seragam dan seimbang antara panjang dan berat (nilai mendekati 3) yang lebih rendah dari SKJ dari perairan Barat Daya Atlantik Selatan (Andrade dan Campos 2002). Kondisi ini juga mengindikasikan bahwa perairan tersebut memiliki daya dukung yang baik terhadap pertumbuhan ikan cakalang.

\section{KESIMPULAN}

Ikan Cakalang (SKJ) di selatan Jawa umumnya adalah ikan yang relatif muda yang tertangkap, dengan kondisi yang sebagian besar belum matang gonad. Ikan yang mencapai populasi dewasa tercatat sangat rendah (21\%) yang menjadi indikator bahwa kondisi perairan termasuk baik dan mendukung bagi perkembangan populasi ikan cakalang. Namun dalam jangka panjang, harus tetap memperhatikan kehati-hatian dalam eksploitasinya.

\section{DAFTAR PUSTAKA}

Anggraeni R, A Solichin, SWS Putra. 2015. Beberapa Aspek Biologi Ikan Cakalang (Katsuwonus pelamis) dalam Kaitannya untuk Pengelolaan Perikanan di PPP Sa-, deng Kabupaten Gunungkidul Yogyakarta. Diponegoro Journal Of Maquares 4(3): 230-239.

Ashida H, T Tanabe, K Satoh, A Fukui, S Tanaka, N Suzuki. 2010. Reproductive biology of male skipjack tuna Katsuwonus pelamis (Linnaeus) in the tropical western and central Pacific Ocean. Fish Sci 76: 785-793

Ashida H, Masahiro H. 2015. Reproductive condition, spawning season, batch fucundity and spawning fraction of skipjack tuna (Katsuwonus pelamis) caught around Amami-Oshima, Kagoshima, Japan. Fish Sci 81: 861-869.

Andrade HA, RO Campos. 2002. Allometry coefficient variations of the length-weight relationship of skipjack tuna (Katsuwonus pelamis) caught in the southwest South Atlantic. Fisheries Research, 55 : 307-312.

Collette BB, CE Nauen. 1983. FAO species catalogue.Vol. 2. Scombrids of the world. An annotated and illustrated catalogue of tunas, mackerels, bonitos and related species known to date. Food and Agriculture organization of the United Nations (FAO) Fisheries Synopsis number 125, volume 2.

Effendie MI. 2002. Biologi Perikanan. Yayasan Pustaka Nusatama. Yogyakarta (ID). 163 hal.

Eveson JP, J Million, F Sardenne, Gaël Le Croizier. 2015. Estimating growth of tropical tunas in the Indian Ocean using tag-recapture data and otolith-based age estimates. Fisheries Research 163: 58-68.

Grandea M, H Murua, I Zudaire, N Gõni, N Bodin. 2014. Reproductive timing and reproductive capacity of the Skipjack Tuna (Katsuwonus pelamis) in the western Indian Ocean. Fisheries Research 156: 14-22.

Hallier JP, A Fonteneau. 2015. Tuna aggregation and movement from tagging data: A tuna "hub" in the Indian Ocean. Fisheries Research 163: 34-43.

Jamal M, MFA Sondita, J Haluan, B Wiryawan. 2011. Pemanfaatan Data Biologi Ikan Cakalang (Katsuwonus pelamis) dalam Rangka Pengelolaan Perikanan Bertanggung Jawab di Perairan Teluk Bone. Jurnal Natur Indonesia 14(1) : 107-113.

Jatmiko I, H Hartaty, A Bahtiar. 2015. Biologi Reproduksi Ikan Cakalang (Katsuwonus pelamis) di Samudra Hindia Bagian Timur. BAWAL 7(2): 87-94

Karman A, S Martasuganda, MFASondita, MS Baskoro. 2014. Capture Fishery Biology of Skipjack in Western and Southern Waters of North Maluku Province. International Journal of Sciences: Basic and Applied Research (IJSBAR) 16(1): 432-448. 
Koya KPS, KK Joshi, EM Abdussamad, P Rohit, M Sivadas, S Kuriakose, S Ghosh, M Koya, HK Dhokia, D Prakasan, VAK Koya, M Sebastine. 2012. Fishery, biology, and stock structure of skipjack tuna, Katsuwonus pelamis (Linnaeus, 1758) exploited from Indian waters. Indian Journal Fish 59(2): 39-47.

Lahodey P, I Senina, R Murtugudde. 2008. A spatial ecosystem and populations dynamics model (SEAPODYM)-Modeling of tuna and tuna-like populations. Oceanography 78: 304-318

Manik Nurdin. 2007. Beberapa Aspek Biologi Ikan Cakalang (Katsuwonus pelamis) di Perairan Sekitar Pulau Seram Selatan dan Pulau Nusa Laut. Oseanologi dan Limnologi di Indonesia 33: 17-25.

Mardlijah S, MP Patria. 2012. Biologi reproduksi ikan madidihang (Thunnus albacares; Bonnatere 1788) di Teluk Tomini. J Lit Perikanan Ind 4 (1) :27-34.

Orange C J. 1961. Spawning of Yellowfin Tuna and Skipjack in the Eastern Tropical Pacific, As Inferred From Studied of Gonad Development. Bulletin Inter-American Tropical Tuna Commission 5(6): 459-496.

Purwanto G, BW Osse, S Bustaman. 1986. Studi pendahuluan keadaan reproduksi dan perbandingan kelamin ikan cakalang (Katsuwonus pelamis) di perairan sekitar Teluk Piru dan Elpaputih, Pulau Seram. Jurnal Penilitian Perikanan Laut 34: 69-78.

Rochman F, B Nugraha, A Wujdi. 2015. Pendugaan Parameter Populasi Ikan Cakalang (Katsuwonus pelamis, Linnaeus, 1758) di Samudra Hindia Selatan Jawa. BAWAL 7 (2) :77-85

Robert M, L Dagorn, JL Deneubourg. 2014. The aggregation of tuna around floating objects: What could be the underlying social mechanisms? Journal of Theoretical Biology 359: 161-170.

Spare P, SC, Venema. 1999. Introduksi pengkajian stok ikan tropis buku i-manual (edisi terjemahan). Kerja sama Organisasi Pangan, Perserikatan Bangsa-bangsa dengan Pusat Penelitian dan Pengembangan Pertanian. Jakarta (ID). 438 hal.

Steel RGD, JH Torrie. 1980. Principles and Procedure of Statistic: a Biological Approach. New York (NY): Mic Grow Hill Bool Company, Inc.

Sumadhiharga K, FD Hukom. 1987. Hubungan panjang berat, makanan dan reproduksi ikan cakalang (Katsuwonus pelamis) di Laut Banda. Makalah pada Kongres Biologi Nasional VIII. Purwokerto.

Suwartana A. 1986. Struktur populasi ikan cakalang (Katsuwonus pelamis) di Maluku Tengah. Jurnal Penelitian Perikanan Laut 34: 99-109.

Udupa KS. 1986. Statisticalmethod of estimating the size at first maturity in fishes. ICLARM, Metro Manila. Fishbyte 4(2) 8-10.

Uktolseja JCB. 1987. Estimated growth parameters and migration of skipjack tunaKatsuwonus pelamis In: Balai Penelitian Perikanan Laut. The Eastern Indonesian Water Through Tagging Experiments. Jakarta.

Uktolseja JCB. 1989. The status of the Indonesian tuna fisheries. Report of the 3rd Southeast Asian Tuna Conference. Bali, Indonesia. 22 - 24August, 1989. IPTPFAO: 66-81.

Walpole RS. 1995. Pengantar Statistika. Jakarta (ID): PT Gramedia Pustaka Umum. 515 hal.

Welcomme RL. 2001. Inland Fisheries: Ecology and Management. London Fishing News Book. A Division of Blackwell Science: $358 \mathrm{p}$. 